Diabetologia 4, 195-202 (1968)

\title{
Serum Insulin in Acromegaly
}

\author{
Comparative Investigations by a Radio-Immunological Method and the Biological Methods \\ Using Adipose and Muscle Tissue*
}

\author{
H. Liebermetster, H. G. Solbach, W.H. Schmling, R. Rügnauver, H. Metssner, D. Grüneklee, \\ L. Herberg, and H. Daweke
}

II. Medizinische Universitäts-Klinik und Diabetesforschungs-Institut an der Universität Düsseldorf

(Direktor: Prof. Dr. K. ObERdiss:)

Received: Oktober 26, 1967

Summary. The response of serum insulin to $100 \mathrm{~g}$ of glucose by mouth was determined in 23 acromegalics simultaneously by radiömmunoassay and by assay on adipose tissue and muscle. The values obtained were compared with those of a normal group. 8 patients suffered from active acromegaly, and 15 were in an inactive phase of the disease. The method used by us for the determination of insulin-like activity on mouse-diaphragm in vivo is described. 1. After an oral glucose load, the changes in the concentrations of serum insulin, determined by radioimmunoassay, and of insulin-like activities, estimated by assay on adipose tissue and muscle, were largely parallel. - 2. At all interval serum insulin levels were higher in the acromegalic group than in the normal one. 3 . Patients with active acromegaly showed significantly higher 1 and $2 \mathrm{~h}$ values than the group with inactive acromegaly. - 4. No significant differences of insulin concentrations were found between the acromegalic groups with and without impairment of carbohydrate tolerance. - 5. In four patients investigated before and after irradiation or operation of the pituitary, there was a significant drop of serum insulin 1 and $2 \mathrm{~h}$ after oral glucose. -6 . Comparing the various insulin levels in the subgroups with different degrees of activity of acromegaly and in the patients seen before and after therapy, we found a parallel change of the "Insulinogenic Index" (SELTZER). - There is good agreement between the response of serum insulin as determined by radioimmunoassay and that of the insulin-like activity measured on fat and muscle tissue, in acromegaly. Each of the three methods used permits the assessment of the degree of activity of an acromegaly and the success of an intervention.

L'insuline sérique dans l'acromégalie. Détermination simultanée avec un dosage radioimmunologique et avec deux méthades biologiques employant le tissu adipeux et le muscle

Résumé. La réponse de l'insuline sérique à $100 \mathrm{~g}$ de glucose par voie orale a été déterminée chez 23 acromégales simultanément par la méthode radioimmunologique et par deux méthodes biologiques employant le tissu adipeux et le muscle. Les résultats obtenus ont été comparés à ceux d'un groupe normal. 8 malades souffraient d'une acromégalie évolutive tandis que 15 étaient dans une phase non-évolutive de la maladie. La méthode employée par nous pour la détermination de l'activité insulino-semblable en employant le diaphragme de la souris in vivo est décrite. - 1. Les variations de concentration de l'insuline sérique après surcharge orale. de glucose déterminées par dosage radioimmunologique et

* We wish to express our gratitude to the Deutsche Forschungsgemeinschaft and the Landesamt fuir Forschung of Nordrhein-Westfalen for grants which made this work possible. celles des activités insulino-semblables estimées sur les tissus adipeux et musculaire étaient d'un parallélisme remarquable. - 2. Pour tous les prélèvements l'insuline dans le sérum était plus élevée dans le groupe acromégale que dans le groupe normal. - 3. Les malades avec une acromégalie évolutive montraient des taux d'insuline significativement plus élevés à 1 et 2 heures que le groupe avec acromégalie non-évolutive. - 4. Nous n'avons pas trouvé de différence significative des concentrations d'insuline entre les groupes d'acromégales avec ou sans diminution de la tolérance au glucose. -5 . Chez 4 malades examinés avant et après irradiation ou opération de l'hypophyse, nous avons noté une chute significative des taux d'insuline 1 et $2 \mathrm{~h}$ après glucose par voie orale. - 6. Comparant les variations des taux d'insuline dans les groupes avec différents degrés d'évolution de l'acromégalie avant et après thérapie, nous avons trouvé un changement parallèle de l' "Index insulinogénique" (SELTzer). - La réponse de l'insuline dans le sérum déterminée par la méthode radioimmunologique correspond de près aux résultats qu'on obtient par la détermination de l'activité insulino-semblable en employant le tissu adipeux et le muscle. - Chacune des trois méthodes employées permet une évaluation du degré d'évolution d'une acromégalie et du succès d'une intervention.

Seruminsulin bei Akromegalie. Vergleichende Bestimmung mit einer radioimmunologischen und den biologischen Methoden am Fettgewebe und Muskel.

Zusammenfassung. Bei 23 Akromegalen wurde radioimmunologisch und am Fettgewebe und Muskel das Verhalten des Seruminsulins unter einer oralen Glucosebelastung untersucht und einem normalen Vergleichskollektiv gegenübergestellt. Es handelte sich um 8 Personen mit progredienter und 15 Personen mit zur Zeit der Untersuchung inaktiver Akromegalie. Das von uns angewandte Insulinbestimmungsverfahren am Muskel wird näher erläutert. Folgende Befunde wurden erhoben: 1. Die Konzentrationsänderungen des radioimmunologisch nachweisbaren Insulins und der am Fettgewebe und Muskel gemessenen insulinähnlichen Aktivitäten unter oraler Glucosegabe verliefen weitgehend parallel. -2 . Die Insulinspiegel lagen für alle Abnahmezeitpunkte bei den Akromegalen deutlich höher als beim Normalkollektiv. 3. Bei Patienten mit progredienter Akromegalie fanden sich signifikant höhere 1- und 2-Std-Werte als bei dem Teilkollektiv mit inaktiver Akromegalie. - 4. Zwischen den Seruminsulinkonzentrationen bei Akromegalen mit und ohne diabetische Stoffwechselstörungen ergaben sich keine signifikanten Untersehiede. - 5. Bei 4 untersuchten Fällen führte die Hypophysenbestrahlung oder -operation zu einem signifikanten Abfall des Seruminsulins 1 und 2 Std nach Glucosegabe. - 6. Den unterschiedlichen Insulinkonzentrationen in den Teilkollektiven mit verschiedenen Schweregraden der Akromegalie sowie vor und 
nach Behandlung entsprachen gleichsinnige Veränderungen des "Insulinogenic Index" nach Sextzer. - Das Verhalten der biologisch nachweisbaren insulinähnlichen Aktivität und des radioimmunologisch gemessenen Insulins stimmen bei der Akromegalie überein. Jede der drei angewandten Methoden erlaubt Aussagen über den Akti- vitätsgrad einer Akromegalie und über den Erfolg eines Eingriffs.

Key-words: Acromegaly, progressive, inactive, treatment, immunoreactive insulin, ILA determined on fat pad, ILA determined on muscle.
Among the forms of diabetes induced by hormones the occurence of diabetic disturbances in acromegaly has been the subject of particular interest since the work of B.A. Houssay [15] and F.G. Young [56] on the interrelationships between the anterior pituitary and carbohydrate metabolism. Increases in serum insulin levels after administration of growth hormone have been demonstrated in men and animals [3, 16 , $17,20,32,39]$.

Already in 1930, OPPENHEIMER observed a pronounced lowering of blood sugar levels several hours after glucose loading in acromegaly, and concluded that in this disease, even in cases with impaired glucose tolerance, the islet cell system must be 'intact, indeed it must be functioning very efficiently' [29]. This assumption was proved experimentally by RANDLE, who demonstrated increased insulin levels in acromegaly using the isolated rat diaphragm [38], and later by other authors using radioimmunological procedures $[1$, $4,16,43,58]$. The method for the determination of insulin-like activity (ILA) in fat tissue gave only increased fasting levels $[23,41]$. The radioimmunological methods used predominantly in these investigations do not, however, permit unequivocal statements about the biological activity of the concentrations of insulin found thereby in the serum $[23,32]$.

It seemed therefore, of interest, to examine if, and to what extent, insulin-like activity determined in muscle, and adipose tissue, and immuno-reactive insulin show parallel behaviour in this disease. Investigations of this type have not, to our knowledge, been described before. Patients with acromegaly appear to be especially suitable since they may be expected to show pronounced variations in serum insulin levels depending on the severity of the disease or on the success of a specific therapy.

\section{Patients}

The investigations were carried out on 23 inpatients of our endocrinological ward. Details are given in Table 1 . There were 14 men and 9 women, with an average age of $42 \mathrm{yr}^{1}$

In order to divide this group into patients with progressive and inactive forms of acromegaly careful evaluations of anamnestical data on the course of the disease were required. Reports of progressive acral growth (which was checked whenever possible by comparison with earlier photographs in order to achieve objectivity), of increasing headaches, heavy perspira-

\footnotetext{
1 One girl, age 9 yrs, suffered from gigantism
}

Table 1. Clinical data in 23 patients with acromegaly

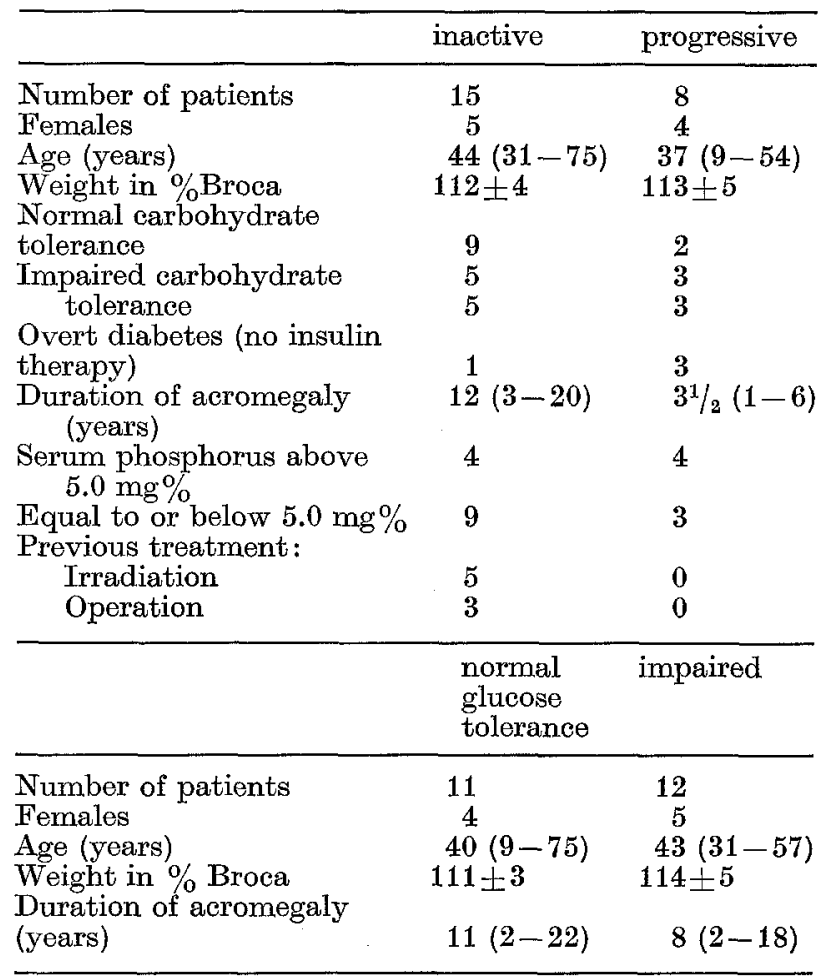

$\bar{x} \pm$ SEM, range in brackets.

tion, general disability and a recent increase in thyroid size as an expression of splanchnomegaly, were regarded as signs of progression. Disturbances in menstruation or sexual ability were reported by several patients of both groups, but did not permit any essential conclusions as to the progression of the disease. An important diagnostic criterion was, however, the finding of bitemporal hemianopsia with deterioration of peripheral vision which increased in subsequent tests. Increases in inorganic serum phosphorus, in the sulphate ion or in alkaline phosphatase as well as a decrease in glucose tolerance were, together with the clinical facts described above, taken as an additional indication of a progressive form of hypersomatotropism.

The classification of the patients took place before the insulin tests. Two of the patients classified as having inactive acromegaly were examples of anterior lobe insufficiency after extirpation of an adenoma several years ago; five other patients in this group had received irradiation of the sella area with doses between 3000 and $6000 \mathrm{r}$, only one of them showed signs of 
anterior lobe insufficiency. The average weight of both the groups, with and without progressive acromegaly, was almost identical. We assumed impaired carbohydrate metabolism if one or both of the glucose tolerance tests (100 $\mathrm{g}$ of glucose orally, $25 \mathrm{~g}$ of glucose i. v.) showed pathological curves as already described in our publications [45]. It was possible to investigate four of the patients before and from 1 to $21 / 2$ yrs after treatment. Two of these received pituitary X-ray treatment with $5000 \mathrm{r}$, one with $10000 \mathrm{r}$ and in the fourth patient an eosinophilic adenoma was removed.

Control subjects had to satisfy the following preconditions: negative family history as far as diabetes was concerned, no reports of stillborn or oversize babies, body weight within plus or minus $15 \%$ of the norm as defined by BRocA, absence of diseases affecting carbohydrate metabolism, e.g. hyperlipaemia, thyroid diseases, kidney disorders, infections, ulcers of the gastronitestinal tract etc; no ingestion of such substances as diuretics, steroids, anti-conceptives, ganglia blockers, which in certain circumstances show diabetogenic activity. Patients showing physical inactivity or caloric malnutrition were also excluded. All control subjects showed normal results in both glucose tolerance tests [45].

\section{Methods}

Prior to glucose loading, patients and control subjects followed a normal diet and observed an overnight fast. They received $100 \mathrm{~g}$ of glucose orally. $30 \mathrm{ml}$ of venous blood was taken before and 30,60,120 and 180 min after glucose loading. Serum was pipetted at room temperature and stored frozen at $-12{ }^{\circ} \mathrm{C}$ for at least three weeks.

Blood sugar was measured by the auto-analyzer method [12], immunologically reactive insulin (IRI) was determined according to the method of HaLES and RANDLE [14] method C., and insulin-like activity in rat adipose tissue (FILA) was assayed using the method of Martin, Renold and Dagknais [24:] as modified by DAWEKE $[6]$ with a serum dilution of $1: 4$. Insulin-like activity in muscle (MILA) was assayed with serum diluted $1: 2$ with a method based on the work of RAFAELSEN [35] comparable with the procedure used by Moody and Felber [28].

We used male albino mice (NMRI-Haackh, Fa. Brünger, 4801 Bokel) weighing between 15 and $18 \mathrm{~g}$, maintained on a diet of mixed rat food (Fa. Höveler, 4018 Langenfeld-Immigrath, Reg. 31 13/64). The mice were fasted, but with free access to water, $12-18 \mathrm{~h}$ before the assay. Both the standard solutions of insulin, containing 50 and $800 \mu \mathrm{U} / \mathrm{ml}$ (crystalline beef insulin $27 \mathrm{IU} / \mathrm{mg}$, Farbwerke Hoechst), were prepared with Krebs-Ringer-bicarbonate (KRB) buffer containing $1 \%$ highly purified bovine albumin (Behring Werke, Marburg RHD 20) [48]. The serum was diluted $1: 2$ with insulin-free buffer solution. The serum and buffer were gassed for $10 \mathrm{~min}$ at $37^{\circ} \mathrm{C}$ with $95 \% \mathrm{O}_{2}: 5 \% \mathrm{CO}_{2}$. D-glucose-U- ${ }^{14} \mathrm{C}$ (The Radiochemical Centre, Amer- sham, U.K., $2.9 \mathrm{mC} / \mathrm{mM}$ ) was added to give a final concentration of $0.4 \mu \mathrm{C} / \mathrm{ml}$. The animals received intraperitoneally in the median line of the lower abdomen $1 \mathrm{ml}$ of either standard or diluted serum. In order to minimise loss from the peritoneal cavity we put a drop of glue (Isar-Chemie GmbH., 8 München ISA-Met A) on the site of injection. Each solution was injected into four animals. We needed therefore 24 mice per patient and glucose load.

The animals were decapitated after $1 \mathrm{~h}$, and the diaphragm was quickly excised, avoiding contamination with liver tissue. The diaphragm was washed in KRB buffer and dried with filter paper. Glycogen was prepared according to WALAAS and WALAAS [50] by putting the muscle into $1 \mathrm{ml}$ of hot $30 \% \mathrm{KOH}$ solution in a glass tube, and boiling for $20 \mathrm{~min}$. Two drops of $10 \% \mathrm{ZnSO}_{4}$ solution and $3 \mathrm{ml}$ of $65 \%$ ethanol were added. After standing for several hours at $+4^{\circ} \mathrm{C}$, the solution was centrifuged at $350 \mathrm{x}$ g for $10 \mathrm{~min}$, the supernatant was discarded and the precipitate washed with $3 \mathrm{ml} 65 \%$ ethanol. After one more centrifugation at $350 \mathrm{xg}$ for $20 \mathrm{~min}$, the precipitate was dissolved in $1 \mathrm{ml}$ of distilled water and transferred to pre-numbered counting platelets. These are dried at $50^{\circ} \mathrm{C}$ for $12 \mathrm{~h}$, and then counted in a gas flow counter (Friesecke and Hoepfner GmbH, 852 Erlangen-Bruck, F.H. 407).

The means of the square roots of counts/diaphragm per minute were recorded on semi-logarithmic paper against the decimal logarithms of insulin concentrations. The unknown concentrations could then be obtained using the straight line between the mean values of the two insulin standards. The precision index $\lambda=$ $\mathrm{s} / \mathrm{b}[9]$ was then calculated according to BorTH et al. [2]. The assays reported here had a mean $\lambda$ of 0.33 , well within the range reported by others [23]. Assays whose $\lambda$ was above 0.50 were discarded and repeated. We also calculated the "Insulinogenic Index" according to SELTZER [46], i.e. the quotient obtained by dividing the difference between the insulin concentrations in fasting serum and in serum $60 \mathrm{~min}$ after glucose, by the difference in blood sugar levels at those points. The results are given as means \pm standard error of the mean (SEM), and the number of assays in brackets. Significance calculations were carried out, if nothing is indicated to the contrary, using the distribution-free Wilcoxon test (Geigy Tables, 6th Ed.).

\section{Results}

A. Carbohydrate Metabolism. As shown in Fig. 1, mean blood sugar levels after glucose loading in the group with inactive acromegaly were within normal tolerance limits ( $x \pm 2$ SD), but they were markedly elevated in the group suffering from acromegaly in the progressive phase. The differences between the two groups were highly significant; likewise the difference between the values of the normal group compared with the total group of acromegalics. Blood sugar curves fell markedly in the four patients examined before and after treatment. In spite of the small number, the 
difference in the fasting values was shown to be significant by the Student $t$ test when corresponding values were matched.
BS $\mathrm{mg} \%$
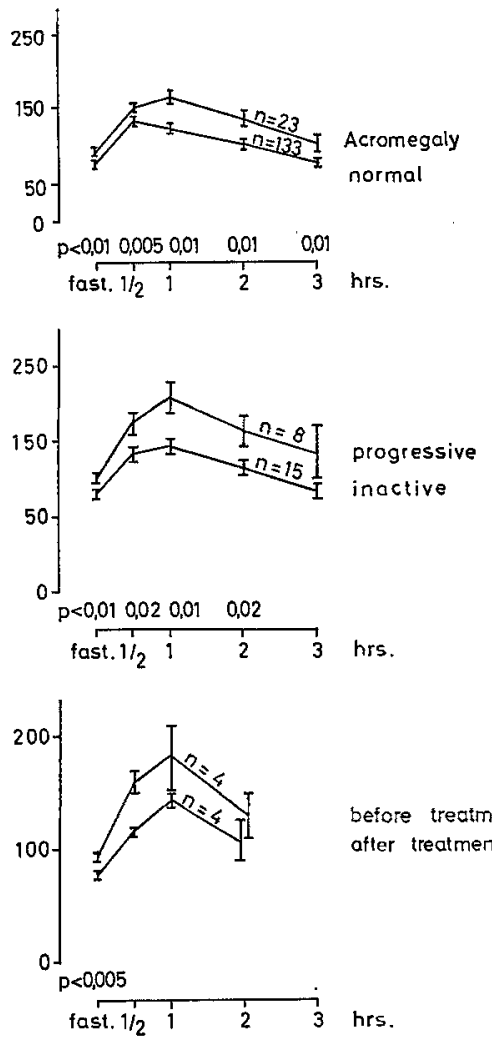

$\mid \mathrm{RI} \mu \mathrm{U} / \mathrm{ml}$
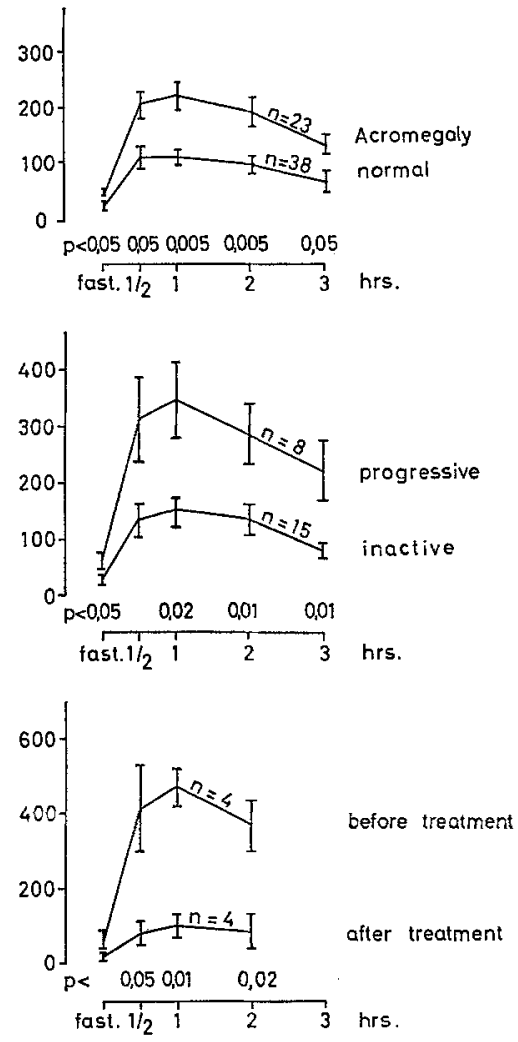

( $\bar{x} \pm$ SEM)

Fig. 1. Blood sugar and immunoreactive serum-insulin in acromegaly after $100 \mathrm{~g}$ of glucose orally
B. Immunoreactive Insulin (IRI). At all intervals with the exception of the $30 \mathrm{~min}$ value - IRI levels in the patients with progressive acromegaly were significantly higher than those in the group with inactive acromegaly (Fig. 1). The differences between the acromegaly-group as a whole and the normal control group were also highly significant. The four patients examined after treatment had IRI levels below normal. The decrease was significant for all intervals that were investigated after glucose by matched comparison (t-test).

IRI levels were higher in 12 acromegalics with decreased glucose tolerance than in 11 patients with acromegaly and normal tolerance, but this difference was not statistically significant (Table 2). The insulinogenic indices of patients with progressive acromegaly were twice as high as those in patients in the inactive phase. In the four patients examined before and after treatment we noted a sharp drop in the indices, but because of the small number of patients involved, it was not possible to prove the statis. tical validity of the difference (Table 3). There were no clear-cut differences in the indices for the sub-groups with normal and impaired glucose tolerance (Table 3 ).

C.Insulin-like Activity determined on Adipose Tissue (FILA). At all times during the oral GTT the values of FILA in the group with progressive acromegaly were higher

Table 2. Blood-sugar and serum-insulin levels in 23 patients with acromegaly subdivided according to glucose-tolerance

\begin{tabular}{|c|c|c|c|c|c|c|}
\hline & fasting & 30 & 60 & 120 & 180 min after & $100 \mathrm{~g}$ glucose orally \\
\hline $\begin{array}{l}\text { Blood-sugar (mg\%) } \\
\text { Both GTT normal } \\
1 \text { or } 2 \text { GTT abnormal } \\
\text { Significance }\end{array}$ & $\begin{array}{l}81 \pm 4 \\
98 \pm 4 \\
+\div\end{array}$ & $\begin{array}{l}128 \pm 8 \\
171 \pm 11 \\
++\end{array}$ & $\begin{array}{l}131 \pm 8 \\
198 \pm 15 \\
+++\end{array}$ & $\begin{array}{l}101 \pm 6 \\
165 \pm 13 \\
++t\end{array}$ & $\begin{array}{r}80 \pm 11 \\
127 \pm 25 \\
+\end{array}$ & $\begin{array}{l}(11) \\
(12)\end{array}$ \\
\hline $\begin{array}{l}\text { IRI }(\mu \mathrm{U} / \mathrm{ml}) \\
\text { Both GTT normal } \\
1 \text { or } 2 \text { GTT abnormal }\end{array}$ & $\begin{array}{l}32 \pm 8 \\
54 \pm 8\end{array}$ & $\begin{array}{l}180 \pm 52 \\
220 \pm 51\end{array}$ & $\begin{array}{l}171 \pm 40 \\
262 \pm 53\end{array}$ & $\begin{array}{l}150 \pm 39 \\
227 \pm 44\end{array}$ & $\begin{array}{l}118 \pm 35 \\
137 \pm 37\end{array}$ & $\begin{array}{l}(11) \\
(12)\end{array}$ \\
\hline $\begin{array}{l}\text { FILA }(\mu \mathrm{U} / \mathrm{ml}) \\
\text { Both GTT normal } \\
1 \text { or } 2 \text { GTT abnormal }\end{array}$ & $\begin{array}{l}361 \pm 60 \\
370 \pm 71\end{array}$ & $\begin{array}{l}981 \pm 276 \\
767 \pm 220\end{array}$ & $\begin{array}{l}1016 \pm 218 \\
1388 \pm 298\end{array}$ & $\begin{array}{l}807 \pm 173 \\
836 \pm 194\end{array}$ & & $\begin{array}{l}(11) \\
(12)\end{array}$ \\
\hline $\begin{array}{l}\text { MTLA }(\mu \mathrm{U} / \mathrm{ml}) \\
\text { Both GTT normal } \\
1 \text { or } 2 \text { GTT abnormal }\end{array}$ & $\begin{array}{l}233 \pm 41 \\
281 \pm 55\end{array}$ & $\begin{array}{r}1009 \pm 293 \\
513 \pm 120\end{array}$ & $\begin{array}{r}827 \pm 293 \\
1205 \pm 318\end{array}$ & $\begin{array}{l}695 \pm 240 \\
679 \pm 242\end{array}$ & & $\begin{array}{l}(11) \\
(12)\end{array}$ \\
\hline
\end{tabular}

$\bar{x} \pm$ SEM, number of determinations in brackets.

$p$ below: $0.05=+, \quad 0.01=++, \quad 0.005=+++$.

Abbreviations : IRI = Immunoreactive insulin, FILA $=$ insulin-like activity determined on fat tissue, MILA = insulin-like activity determined on muscle tissue. 
than those in the group with inactive acromegaly (Fig. 2). Despite marked variance this difference is statistically significant for the $1 \mathrm{~h}$ value. FILA values 1 and $2 \mathrm{~h}$ after glucose were also significantly

$$
\frac{F \mid L A \mu U / m !}{(1: 4 \text { dIl. })}
$$

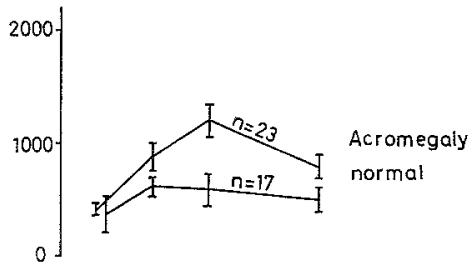

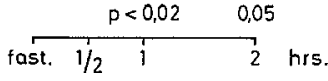
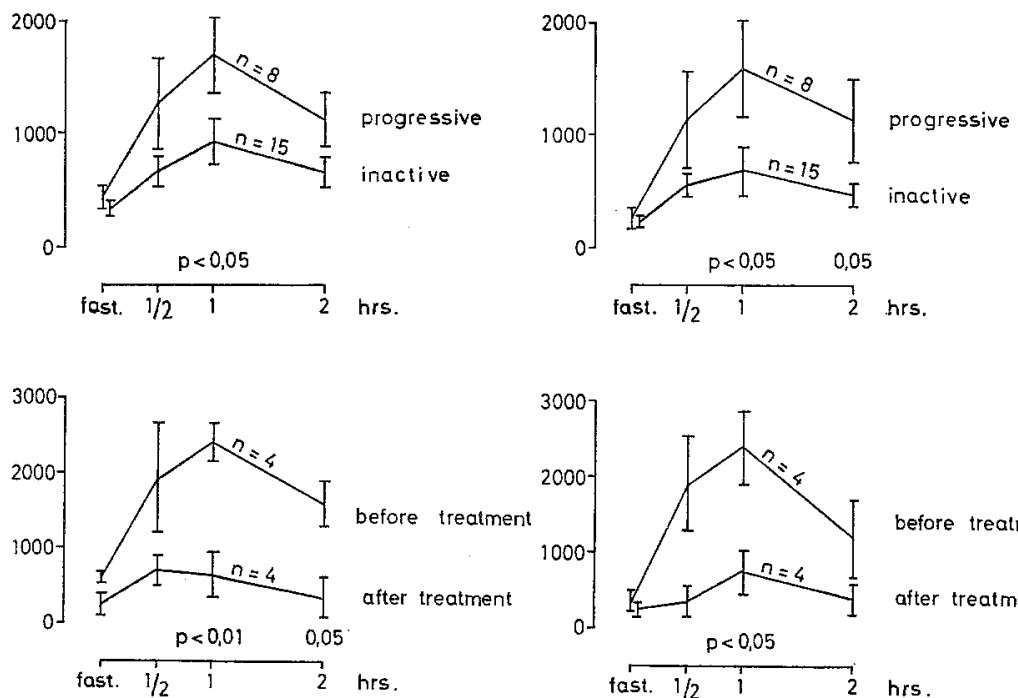

$(\bar{x} \pm S E M)$

Fig. 2. Insulin-like activity on adipose and muscle tissue in acromegaly after $100 \mathrm{~g}$ of glucose orally acromegalics with diabetic disturbances of carbohydrate metabolism were only slightly different from values obtained with 11 acromegalics with normal glucose tolerance (Table 3 ).

Patients with progressive acromegaly had a Secrater index that was twice as high as patients in the inactive phase of the disease (Tab. 3). The same result is found on comparison of the total group with acromegaly with the normal control group. Acromegalic patients with disturbed carbohydrate tolerance had a lower index than acromegalics with normal carbohydrate metabolism.

Treatment of four patients with progressive acromegaly, investigated before and after therapy, led to a marked fall in the "insulinogenic index", as demonstrated in Table 3.

$D$. Insulin-like Activity determined in Muscle (MILA). With this method we also found markedly higher levels in patients with progressive acromegaly than in patients with inactive hypersomatotropism. (Fig. 2). The differences between the normal group and the total group of acromegalics were significant at every interval investigated. Because of the small number of cases a therapeutic effect on MILA levels could only be proved statistically for the $1 \mathrm{~h}$ interval. Comparison of the groups with and without disturbance of glucose tolerance indicates only a delayed increase in serum MILA levels after glucose in patients with latent or manifest diabetes (Table 2). Otherwise there are no unequivocal differences in MILA concentrations be-

\begin{tabular}{|c|c|c|c|c|}
\hline & & for IRI & for FILA & for MILA \\
\hline Total group & $(23)$ & $2.75+0.37$ & $12.5+3.0$ & $13.5+4.5$ \\
\hline Progr. Acromegaly & $(8)$ & $4.03 \pm 1.62$ & $18.2 \pm 8.0$ & $24.4 \pm 12.2$ \\
\hline Inactivo Acromegaly & (15) & $2.02+0.32$ & $9.5+2.2$ & $7.7+2.9$ \\
\hline Before therapy & (4) & $6.93+2.52$ & $30.9+13.6$ & $43.7+21.0$ \\
\hline After therapy & (4) & $2.12 \pm 1.43$ & $8.5 \pm 4.5$ & $7.7 \pm 4.8$ \\
\hline Both GTT normal & (11) & $3.60+1.26$ & $15.4+5.7$ & $17.2+8.6$ \\
\hline 1. or GTT abnormal & (12) & $2.04 \mp 0.47$ & $9.4+2.2$ & $9.4+3.7$ \\
\hline Normal Values & & $2.10 \pm 0.31$ & $6.90 \pm 2.64 \quad(10)$ & $5.8 \pm 1.6$ \\
\hline
\end{tabular}

Table 3. The "Insulinogenic Index" of SELTZER in 23 patients with acromegaly

$\bar{x} \pm$ SEM, number of determinations in brackets, for abbreviations see Table 2.

elevated in the total group of acromegalics when compared with the control group. Treatment of acromegaly led to a sharp decrease in FILA levels, significant at the 1 and $2 \mathrm{~h}$ intervals after glucose. Results in 12 tween these two groups. Here also the index is twice as high in the total group of acromegalics as in the control group. In line with the FILA results, the "insulinogenic index" is higher in non-diabetic patients 
and in those with progressive acromegaly when compared with the corresponding control groups. There was also a sharp decline after therapy. The significance of these latter findings could not be proved because of marked variance (Table 3). As indicated in Figs. 1 and 2 , results for the group with inactive acromegaly and the normal group show little difference.

\section{Discussion}

Before evaluation of the results, it is necessary to discuss the question whether elevated somatotropin levels can have influenced the methods of insulin determination. Growth hormone has an insulin-like effect on muscle $[30,36]$ and on adipose tissue $[8,53]$, and it has been reported that it impairs the radioimmunological determination of insulin [56]. This latter assertion has meanwhile been refuted $[26,54]$. RAFAELSEN has demonstrated in the muscle method [36] that at least $10 \mu \mathrm{g}$ of human growth hormone is necessary to produce a small and insignificant increase in glucose incorporated into the glycogen of the diaphragm. This amount is ten times higher than the highest STH concentrations observed in acromegalics receiving glucose [44]. Even larger amounts of human growth hormone are required to provoke an increase in glucose oxidation by the adipose tissue of normal rats $[8,53]$. It is, therefore, unlikely that serum somatotropin levels have influenced our determinations of insulin. The insulin levels determined by these different methods are largely in agreement (Figs. 1 and 2), as far as the form of the curves and the differences between the sub-groups are concerned.

It is not intended to draw conclusions from the observation that the corresponding FILA and MILA values are usually of the same order of magnitude since it was necessary to work with different serum dilutions in the two methods. Both procedures show a well-known dilution effect with an apparent increase in ILA levels, which has been variously interpreted $[22,40,47,52]$. The possibility of differences in species must also be considered [48a] since we used rats for the FILA and mice for the MILA investigations.

The question arises whether there are relationships between the degree of activity of acromegaly and serum insulin levels. WRIGHT did not find indications pointing to this assumption when determining glucose uptake of isolated rat-diaphragms as influenced by the sera of 14 acromegalics [55]. In contrast with these results, KARAM et al. found distinctly higher IRI levels in their 10 cases of active acromegaly from a total of 17 acromegalies, but could demonstrate no significance since blood had been withdrawn at different intervals [16]. Our investigations using three different methods of insulin determination indicate a significant increase in insulin levels 1 and $2 \mathrm{~h}$ after glucose in patients with progressive acromegaly compared with a group with inactive acromegaly (Figs. 1 and 2). We must therefore consider whether the higher levels of serum insulin that we found in patients with progressive acromegaly are not due to the fact that this group contains more persons with impaired carbohydrate tolerance (Table 1 ).

As a rule, persons with disturbances in carbohydrate metabolism show increased insulin levels only if they are overweight at the same time $[7,18,19]$. As indicated in Table 1 , relative overweight, average age, and mean duration of acromegaly are in good accord for the groups with normal and impaired glucose tolerance. Serum insulin levels are, as demonstrated in Table 2, not significantly different in the two groups. These results are supported by the observations of KARAM et al., who also found no correlation between the degree of diabetic disturbance in acromegaly and IRI levels [16]. In order to judge the influence of pituitary-induced impairments of carbohydrate metabolism, it would be interesting to know the duration of diabetic disturbances in both sub-groups with active and inactive acromegaly. Since we dealt in the main with cases of latent diabetes detected during our investigations, which were performed ad hoc, this question cannot be answered.

We may conclude, however, that elevated serum insulin levels in patients with progressive acromegaly are not due to a higher proportion of persons with disturbed carbohydrate metabolism in this group. The differences which exist in pituitary-induced diabetes in acromegaly and in genetic diabetes have been dealt with extensively by ZAHND and coworkers [58].

The question remains whether the differences in serum insulin levels in our subgroups with progressive and inactive acromegaly did not arise from the fact that acromegaly had lasted four times as long (Table 1) in the latter group, with ensuing exhaustion of insulinproducing tissues. Although this possibility cannot be excluded, our findings in the four patients investigated before and after treatment of acromegaly strongly indicate that there is not only exhaustion of the islets of Langerhans, but also less stimulation of insulin production in cases of inactive hypersomatotropism. A coworker of H. CusHivg already reported in 1927 that blood sugar curves are largely normalized by removal of the adenoma in acromegalics [5]. Patients after treatment for hypersomatotropism show lower IRI levels when compared with non-treated acromegalics $[16,21,43]$. The marked fall in bloodsugar and serum insulin concentrations that we observed in four patients after irradiation or operation, can be proved to be significant at the 1 and $2 \mathrm{~h}$ intervals after glucose (Figs. 1 and 2) ${ }^{1}$.

These investigations were carried out not earlier than three months after treatment. An anorexia immediately following the intervention, with decreased caloric intake does not, therefore, appear to be the cause of these observations. Serum insulin concentrations as low as those in our acromegalics after treat.

\footnotetext{
1 Similar findings have been reported by R. LUFT, E. Cerast, and C.A. Hambergar (Acta endocr. 56, $593-607,1967)$ after preparation of this manuscript.
} 
ment have also been reported in patients with insufficiency of the anterior lobe $[20,27,37]$.

The calculation of the "Insulinogenic Index" (SELTZER) [46] assists the evaluation of a correlation between increases in the levels of serum insulin and concomitant increases in blood-sugar. As shown in Table 3 , the increases in serum insulin in active acromegaly and before treatment were more than proportional, and therapy led to a normalization of the index. The index was also higher in acromegalics with normal glucose tolerance in comparison with those with impaired carbohydrate metabolism. The pronounced variation inherent in the index calculation did not permit - at least in our relatively small groups - the proof of these results statistically.

Our findings cannot be explained by the disturbances of carbohydrate metabolism alone, which are frequently observed with elevated somatotropin concentrations. This diabetogenic effect has been investigated in vitro in muscle $[42,51]$ and in adipose tissue [11], as well as in vivo on the perfused forearm [34] and with other techniques $[10,17,33]$. From these findings one would expect high levels of growth hormone to lead to a nearly equal rise in blood sugar and insulin levels. The interpretation of our results showing a more than proportionate increase in insulin levels would be facilitated by assuming stimulation of insulin release by growth hormone. This kind of stimulation has been demonstrated in vivo [20,31] and in vitro [25] in recent years in contrast to older findings [13]. LUFT and Cerasi have reported results which are in close accord with ours and were interpreted similarly [21].

The three procedures for the determination of insulin that we have employed can give valuable indication whether a case of acromegaly is progressive, and/or whether therapeutic intervention was successful.

Acknowledgements. Our thanks are due to Frl. BоHMert, Frl. B. Clever, Frl. Drewermann, Fr. L. Miss and Frl. MÜHLENKaMP for their conscientious co-operation.

\section{References}

1. Benedetti, A. : Comparison of plasma insulin response to various stimuli in normal, obese diabetic and acromegalic subjects. Excerpta medica 140, 67 (1967).

2. Borth, R., E. DiczFatusy, u. H.D. Heinnichs: Grundlagen der statistischen Auswertung biologischer Bestimmungen. Arch. Gynäk. 188, 497-538 (1957).

3. CAMPBELI, J., and K.S. RAstogt: Evidence of maintained increase in insulin secretion induced by growth hormone with further augmentation after meals or infusion of glucose, in dogs with portal vein cannulae. Diabetes 14, 444 (1965) abstr.

4. Cerasi, E., and R. LUfT : Insulin response to glucose loading in acromegaly. Lancet 1964 II, $769-771$.

5. DavidofF, L.M., and H. Cushing: Studies in acromegaly. Arch. intern. Med. 39, 751 - 779 (1927).

6. DAWEkE, H. : Bestimmung der insulinähnlichen Aktivität im Blut des Menschen unter normalen und pathologischen Bedingungen. Habil. Schrift Düsseldorf (1964).
7. - H. VAN LANDEGHEM, W. WINKELMANN, u. I. BaOH: Der Einfluß der Adipositas auf die insulinähnliche Aktivität und physiologische Insulinreserve beim Altersdiabetes. Klin. Wschr. 43, 190-96 (1965).

8. Ditschuneit, H., R. Ziegler, u. E.F. Pheifferr: Über die Bestimmung von Insulin im Blut am epididymalen Fettanhang der Ratte mit Hilfe markierter Glucose. V. Mitteilung. Klin. Wschr. 39, 426-430 (1961).

9. Gaddum, S.H.: Bioassays and Mathematics. Pharmacol. Rev. 5, 87-134 (1953).

10. Galbrarth, H.J.B., J. Ginsburg, and A. Paton: Decreased response to intraarterial insulin in acromegaly. Diabetes 9, 459-465 (1960).

11. Goodman, H.M. : A comparative study on the effects of insulin and growth hormone on hexose metabolism in adipose tissue. Endocrinology 80, 45-51 (1967).

12. Grady, H.J. and H.A. Lamar: Glucose determination by automatic chemical analysis. Clin. Chem. 5, $542-550(1959)$.

13. Grodsky, G.M., L. Bennett, A. Batts, N. MoWILLIAMS, and C. VIELLA: Insulin secretion from isolated perfused pancreas. Fed. Proc. 21, 202 (1962).

14. Hales, C.N., and P.J. RANDLE: Immunoassay of insulin with insulin-antibody precipitate. Biochem. J. 88, 137-146 (1963).

15. Houssay, B.A.: The Hypophysis and Metabolism. New Engl. J. Med. 214, $961-986$ (1936).

16. Karam, J.H., G.M. Grodsky, F.C. Pavlatos, and P.H. Forsham: Critical factors in excessive serum insulin response. Obesity in maturity-onset diabetes and growth hormone in acromegaly. Lancet $1965 \mathrm{I}$, $286-289$.

17. KtPNIs, D.M., and M.F. SterN: Insulin antagonism: Fundamental considerations. Ciba Found. Coll. on Endocr. 15, 156-184 (1964).

18. Kreisberg, R. A., B. R. Bosheld, J. Dr Placido, and R.F. Roddam: Insulin secretion in obesity. New Engl. J. Med. 276, 314-319 (1967).

19. Ltebermeister, H., H. Daweke, F.A. Gries, W.H. Schilling, D. Grüneklee, G. Probst, K. Jahnke: Einfluß der Gewichtsredultion auf Metabolite des Kohlenhydrat- und Fettstoffwechsels und auf das Verhalten des Seruminsulins bei Adipositas. Diabetologia 4, 123-132 (1968).

20. LufT, R., and E. Cerasi: Effect of human growth hormone on insulin production in panhypopituitarism. Lancet 1964 II, 124-126.

21. - - Human growth hormone as a regulator of blood glucose concentration and as diabetogenic substance. Vortrag VI. Acta Endocr. Congress, Helsinki 8. - 12. VIII. 1967.

22. LYNGSø, J.: The insulin-like activity in serum determined by the rat epididymal fat method. I. Normal values in undiluted and diluted serum and the effect of ingestion of glucose. Acta med. scand. 171, 365 - 375 (1962).

23. - Seruminsulin. Acta med. scand. 179, suppl. (1965).

24. Martin, D.B., A.E. Renold, and Y.M. Dagenals: An assay for insulin-like activity using rat adipose tissue. Lancet 1963 II, $76-77$.

25. Martin, G.M., J.J. GaGliardino: Effect of growth hormone on isolated pancreatic islands of rat in vitro. Nature (Lond.) 213, 630-631 (1967).

26. Meade, R.C., and J.T. Kuetst: Effect of human growth hormone on methods of insulin immunoassay. Nature (Lond.) 214, 195-196 (1967).

27. Merimít, T.J., J.A. Burgess, and D. Rabinowitz: An influence of growth hormone on insulin release: Studies in growth hormone deficient subjects. Diabetes 15,516 (1966) abstr. 
28. Moody, A.J. and D.P. Fruber : A bioassay for insulin using the in situ mouse diaphragm. Experientia 20, $646-648$ (1964).

29. OPPENHEIMER, A.: Ưber das Wesen der Zuckerkrankheit bei Akromegalie. Klin. Wschr, 9, 17-19 (1930).

30. Park, C.R., D.H. Brown, M. Cornblate, W.H DaUghaday, and M.E. KRAHL: The effect of growth hormone on glucose uptake by the isolated rat diaphragm. J. biol. Chem. 197, 151-166 (1952).

31. PremFurer, E.F.: Wachstumshormon und Insulinsekretion. Die Verhältnisse unter normalen und pathologischen Bedingungen. 11. Symposium Dtsch. Ges. Endokrinologie, S. 41-55. Berlin: Springer 1965.

32. - F. Melant, H. Ditschunett, u. K. Sohöffling: Radioimmunologische Bestimmung des Insulins. Bull. Schweiz. Akad. Med. Wiss. 21, 276-297 (1965).

33. RABEN, M.S.: Growth hormone: Anabolic and anticatabolic agent. Diabetes 13, 651 (1964).

34. RabinowITz, D., and K.L. ZierLer: A metabolic regulating device based on actions of human growth hormone and insulin, singly and together on the forearm. J. clin. Inv. 42, 967 (1963), abstr.

35. RAFAELSEN, O.: Insulin-like activity of human serum determined by glycogen increase of diaphragm after intraperitoneal injection into the intact rat. Acta physiol. scand. 61, 323-330 (1964).

36. - Glycogen content of rat diaphragm after intraperitoneal injection of insulin and other hormones. Acta physiol. scand. 61, 314-322 (1964).

37. RaNDLe, P.J.: Plasma insulin activity in hypopituitarism assayed by the rat-diaphragm method. Lancet 1954 I, $809-810$.

39. - Plasma-insulin activity in acromegaly assayed by the rat-diaphragm method. Lancet 1954 I, 441-445.

39. - , and F.G. Young: The influence of pituitary growth hormone on plasma insulin activity. J. Findocr. 13, 335-348 (1956).

40. Rasio, E.A., J.J. SomLdner, and J. Steinke: Effect of dilution during fractionation and extraction of serum and lymph insulin. Proc. Soc. exp. Biol. (N.Y.) 123, 701-704 (1966).

41. RECANT, L., H. AIPH, M. KocH, and J. EgGgManN: Plasma insulin-like activity (ILA): Insulin plus adipose tissue inhibitors. J. elin. Invest. 42, 968-969 (1963).

42. REGEN, D.M., W.W. Davis, H.E. Morgan, and C.R. PARK: The regulation of hexokinase and phosphofructokinase activity in heart muscle. J. biol. Chem. 239, $43--49$ (1964).

43. Rosselta, G., G. Tschoubroutsky, P. Freychet, R. Assan, et M. Derot: Taux plasmatiques de l'hormone de croissance (H.G.H.) et de l'insuline chez des acromégales traités ou nontraités. Diabetologia $\mathbf{2}$, 217 (1966) abstr.

44. Roth, J., S.M. GLIok, R.S. YALow, and S.A. BeRsox: The influence of blood glucose on the plasma concentration of growth hormone. Diabetes 13, $355-361$ (1964).
45. Sohilting, W.H., K. Oberdisst, K.A. HÜteR, u. H. BLANK: Vergleichende Untersuchungen mit der oralen und intravenösen Glucosebelastung zur Erfassung einer verminderten $\mathrm{KH}$-Toleranz. Diabetologia 1, $187-194(1966)$.

46. Serttzer, H.S., and W.L. Smith: Plasma insulin activity after glucose. An index of insulinogenic reserve in normal and diabetic man. Diabetes $\mathbf{8}$, $417-424$ (1959).

47. Siess, E., A. TEINZER, u. O. Wimland : Eine vereinfachte Fettgewebsmethode zur Insulinbestimmung im Serum. Diabetologia 1, 201-207 (1965).

48. Sönkser, P.H., J.P. Elilis, C. Lowy, A. RutherFORD, and J.D.N. Nabarro: A quantitative evaluation of the relative efficiency of gelatine and albumin in preventing insulin adsorption to glass. Diabetologia $1,208-210(1966)$.

48a) Steinkm J., E. MIKI, G.F. Cahill JUn.: Assay of crystalline insulin and of serum insulin-like activity of different species on adipose tissue of the rat, mouse and guinea-pig. New Engl. J. Med. 273, 1464-1467 (1965).

49. UNGER, R.H.: Glucoregulatory hormones in health and disease. A teleologic model. Diabetes 15, 500-506 (1966).

50. WaIAas, W.O., and W.E. Walaas: Effect of Epinephrine on Rat Diaphragm. J. biol.Chem. 187, 769 - 776 (1950).

51. WEII, R., P.P. Ho, and L.E. SchaEFER : An effect of growth hormone on hexose phosphate metabolism. Proc. Soc. exp. Biol. (N.Y.) 120, 630-632 (1965).

52. Willebrands, A.F., H. v.d. Geld, and J. Groen Determination of serum insulin using the isolated rat diaphragm, the effect of serum dilution. Diabetes $\mathbf{7}$, $119-124$ (1958).

53. Winegrad, A.J., W.N. Shaw, F.D.W. Lukens, W.C. STADIE, and A.E. RENOLD : Effects of growth hormone in vitro on the metabolism of glucose in rat adipose tissue. J. biol. Chem, 234, 1922-1928 (1959).

54. WRIGHT, A.D., T.A. WELBORN, and T.R. FRASER: Effect of Human Growth Hormone on "Insulin Basic Protein Complex". Nature (Lond.) 210, 418 (1966).

55. WRIGHT, P.H.: Plasma Insulin activity in Acromegaly and Spontaneous Hyperglycemia. Lancet 1960 I, $951-954$.

56. Young, J.D., and E.P. GeORGE: Effect of human growth hormone on insulin basic protein complex. Nature (Lond.) 207, 1199 (1965).

57. Young, F.G.: Permanent experimental diabetes produced by pituitary (anterior lobe) injections. Lancet 1937 II, 372-374.

58. ZaHND, G.R., A. LuYckx, and A. Nadeani: Studies on diabetes in active acromegaly. Excerpta med. 140, 125 (1967) abstr.

Dr. H. LTEBERMEISTER

II. Medizinische Klinik und

Poliklinik der Universität

4000 Düsseldorf

Moorenstr. 5 